\title{
THE EFFECT OF ANAGRAM GAMES ON SECONDARY LEVEL STUDENTS' READING ACHIEVEMENT
}

\author{
Endang Sulistianingsih'; Rizki Dwi Juliani2; ${ }^{2}$ Toto Pradjarto ${ }^{3}$ \\ Universitas Pancasakti Tegal 1,2,3
}

Corresponding email: endang.sulistia@gmail.com

\begin{abstract}
The study employed a quantitative approach with Two-Group Design. The population consisted of six classes. We took a sample of two classes, VII-C as the experimental group and VII-D as the control group. Samples were determined using cluster sampling techniques. Based on the writer's observation, some teachers in Junior High School Tegal still used the conventional technique in teaching especially in teaching reading, in fact, reading is very difficult to teach in Junior High School because a lack of vocabulary made the students' motivation declined in reading. The result of the study revealed the use of Anagram was effective in teaching and learning reading. It happened since in Anagram implementation the students as the participants and the teacher as the facilitator. This situation was suited to the curriculum 2013 in which it concerned students oriented. Besides the students had fun and enjoyed reading because they teach each other, it easy to known students' lack and need by Anagram Games, students trained to dare to ask and give their opinion especially in leaning reading which has many words and paragraphs. This method is easier, useful and flexible for the teacher to apply because of no need for a lot of time, media, realia and place. So, this study gives recommendations for teachers and students to implement this method.
\end{abstract}

Keywords: Anagram Games, reading achievement, word games, TEFL, K-12

\section{INTRODUCTION}

In the curriculum of 2013, teachers should be able to make a learning process as attractive as possible during teaching. Attractive learning will make the students increase their motivation and curiosity in learning English. Based on our observation, some teachers in Junior High School Tegal still use conventional teaching techniques in the class especially in teaching reading, in fact, reading is very difficult to teach in Junior High School because of lack of vocabulary will make the students' motivation declined to read.

Muslaini (2017) stated that reading is the process of getting information from the written text, from the writer to the reader. The goal of all reading is the comprehension of meaning that is conveyed in the written 
text. Reading is one of the main skills students must master in a foreign language to successfully learn the language (Rraku, 2013). Students can not be apart from reading because the learning process and teaching always related to it in all learning activities.

In spite of the concept of reading has been applied since elementary school, many students of Junior High School in Tegal feel confused with reading, especially in a long text. Teachers always give the students reading text and questions related to the text and ask the students to read the text carefully and finally they must answer the questions. Then, the students must work individually to do the activity and they do not get a chance to discuss it with their friends.

As with the kind of boring teaching technique, many students feel so difficult to do the activity because they can not discuss it with other students. Finally, they get a bad score and result and also they do not get the best strategy to read easily, so their reading skills cannot be advanced. For all these reasons, an appropriate strategy is needed to facilitate their interest in reading English. This strategy is language learning strategies as learning strategies, social strategies, and communication strategies (Rraku, 2013). Then, a teacher has to select a leaning method based on students' needs and change their minds about bored reading to become fun reading in the learning process and teaching. One teaching strategy that very fun for students is Anagram Games. Based on the writer's experience, studying reading for Junior High School students must be different from Elementary School students or students Senior High School, because they have characteristics. Many students cannot read the English text.

The English text is difficult to be understood because they're vocabulary mastery very less so they feel lazy about reading a long text. They cannot understand the meaning or they don't know how to determine the main idea from the long text. So, the student's motivation in reading is low. Some previous studies have been done by Rahman (2016), Junika and Gintings (2013). Their studies state that Anagram Games is effective in teaching vocabulary. states that anagram is the words or phrases that written trough re-arranging the letters of different words or phrases. An Anagram is a word game that reorders a random word, this activity will encourage students to recall vocabulary in textbooks or books for their notes (Keshta \& Al-faleet, 2013). So, the writer would like to know how the deeper this technique and about the effectiveness of it to analyze students' reading understanding and to know to increase students' reading achievement in learning reading for the first grade of Junior High School in Tegal.

That way, we conducted this research related to the problem with the title: "The Effect of Using Anagram Games on Reading Achievement. (An Experimental Study to the First Grade of Junior High School Tegal in the Academic Year of 2018/2019). 


\section{METHODS}

This research is experimental research. Creswell \& Creswell (2017) states that experimental design is applied behavioral analysis or a single-subject experiment in which experimental treatment is administered over time to a single individual or a small number of individuals. Experimental research is all of the needed processes in the planning and implementation of research. In this research, we used two group designs. They are an experimental group (the implementation of the Anagram Strategy) and the control group (the implementation of TPS Strategy).

In the first meeting of the treatment, we greeted students then checked the attendance. Next, we introduced herself to get a good first impression and explained to the students that the purpose of her attendance was as the teachers in replacement for several meetings. We explained about what Anagram Games was. Then, we gave a descriptive text to students and told the topic of the descriptive text. The teacher explained descriptive texts such as understanding, purpose, generic structure and language features. After students understood from the explanation, the teacher asked students to form groups of 5 children and asked students to read the text and write new words that they didn't know the meaning of and then asked students to find the meaning in the dictionary. In this study, students must bring a dictionary for each meeting.

The teacher explained Anagram Games to students, after that the teacher started using new words that were previously written. Some students asked because they were still confused by how to form new words from words they previously wrote. After forming a new word, students began to practice the questions related to the descriptive text. In the next meeting, the teacher asked students about the material that had been discussed in the previous meeting to find out how far students understood the description text. In this meeting, we wrote and observe student activities during the learning process. After that, the teacher started with a new description text with a different theme from the previous meeting. The learning process was the same as the first meeting.

In the first meeting, students still looked confused with this game, but in the second meeting, students had begun to understand how to apply the Anagram Games in their learning process. In the third meeting, the teacher would explain the other types of Anagram Games implementation so that students were more interested in reading English texts which they found difficult to understand. This learning and teaching process came to the eight meetings of the same type but with different materials. We used two types of texts namely description text and procedure text. But at the eighth meeting, we used reviewed the materials from the beginning of the meeting until the seventh meeting. 


\section{Instruments}

The writer designed a test on a simple multiple-choice form with four options: A, B, C, and D. There were 50 questions that consist of 12 reading text with the right answer scored 1 and for the wrong answer scored 0 and students had to answer in 80 minutes time allocation. The writer took descriptive text and procedure text based on the material of the first-grade students in the syllabus curriculum 2013. These questions used as an instrument for collecting the data.

The instrument of research was given to the class which did not belong to the experimental and control group. We named this class as a tryout class. The students did the try-out test for 80 minutes. This tryout aims to find out whether the test is valid or not. To prove the validity and reliability of the instrument, the writer gave the instrument a try-out test in the try-out class. The writer draws a blueprint of the test as follow:

1. Classification : Cognitive Domain

2. Subject : English Language

3. Topic : Descriptive and Procedure

4. Time Allocation : 80 minutes

Table 1. Instrument Test

\begin{tabular}{|c|c|c|c|c|c|c|c|c|}
\hline \multirow{2}{*}{ Topic } & \multirow{2}{*}{$\begin{array}{l}\text { Level of } \\
\text { Difficulty }\end{array}$} & \multicolumn{6}{|c|}{ Levels of Cognitive } & \multirow{2}{*}{ Total } \\
\hline & & $\mathrm{C} 1$ & $\mathrm{C} 2$ & C3 & C4 & $\mathrm{C} 5$ & C6 & \\
\hline Descriptive & Easy & 2 & 3 & 1 & 1 & - & - & 7 \\
\hline \multirow[t]{2}{*}{ Text } & Middle & 3 & 4 & 3 & 1 & - & - & 11 \\
\hline & Difficult & 2 & 3 & 2 & - & - & - & 7 \\
\hline Procedure & Easy & 2 & 3 & 1 & 1 & - & - & 7 \\
\hline \multirow[t]{2}{*}{ Text } & Middle & 3 & 5 & 2 & 1 & - & - & 11 \\
\hline & Difficult & 2 & 3 & 1 & 1 & - & - & 7 \\
\hline
\end{tabular}

Cognitive domain:

C1 : Recognition

C2 : Comprehension

C3 : Application

C4 : Analysis

C5 : Synthesis

C6 : Evaluation

We used SPSS to check the validity and reliability of the instrument. The validity and reliability criteria for testing the instrument that the writer used based on Brown's (2004) theory. Then we found the result of $r_{x y}=$ 0.462 , the level of significant was $5 \% \mathrm{r}$-table with $\mathrm{N}=30$ was 0.361 . It mean $\mathrm{r}_{\mathrm{xy}}$ higher than $r_{t}(0.462>0.361)$, so the test was "VALID". The next step was to find out whether the test was reliable or not, the writer used the procedure of split- half method by Spearman-Brown. In this technique, we must create a question item analysis table. From the analysis, scores were grouped into 2 
question sections. There were two ways to divide the question section, the first was odd and even, and the second was the first and the second. In this case, the writer uses the second method, it is the first and second split. The results found that $\mathrm{r} 11=0.659$, then the level of significance was $5 \%$ and $\mathrm{r}$ table with $\mathrm{N}=30$ was 0.361 . So, the writer concluded that the test was "RELIABLE" because $r_{11}$ is higher than r-table $(0.659>0.361)$.

\section{Data Analysis Procedures}

Based on the data that had been calculated, the writer gained the united variant formula was 84.67 and the unity of standard deviation (S) was 9.201. To find out if there were significant differences between the first group and the second group then the t-test was conducted. The writer counted the $t$ test, then the calculation showed that the t-test was 3.638 with degree freedom 58 and level of significant $5 \%$ with the t-table 1.672. Because t-ratio was bigger than $\mathrm{t}$-table $(3.638>1.672)$, so $\mathrm{H}_{1}$ was accepted.

\section{FINDINGS}

During the teaching and learning process using Anagram Games, below was the description of that process.

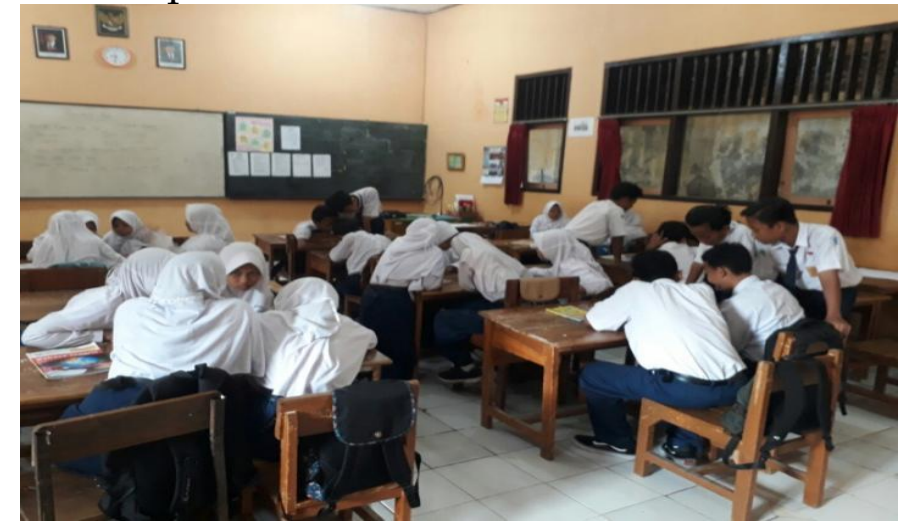

Figure 1. The students work in groups.

Based on the picture above, students formed groups of 4 or 5 people. After forming groups, they read the description text that had been shared by the teacher. Then, the teacher wrote words that look difficult for students on the board. After that, they are asked to form new words according to the words in the writing board. In this activity, students must use a dictionary. 


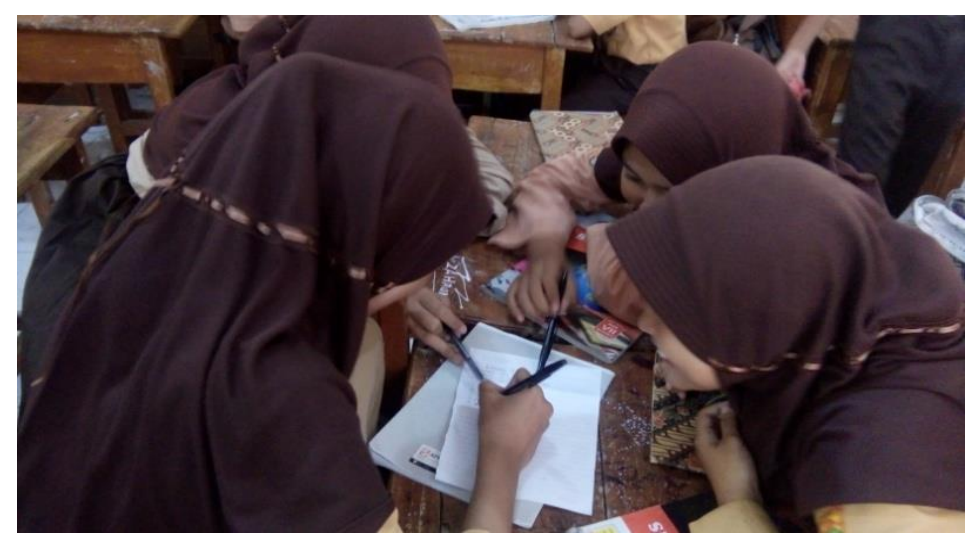

Figure 2. The students work in groups.

Students began to implement Anagram Games in this activity, they looked enjoyed and enthusiastic in this learning process. After finished the word game, students were asked to work on some of the questions below the description text. The aim was to make students want to read texts in English but in a different way using games. Trough this activity students began to dare to ask the teacher, this revealed that they participated in the learning process.

\section{DISCUSSIONS}

Related to the findings, we found several problems during reading class. First, some students made noisy in the class. So the other students did not focus the learning well. Second, some students were passive. Actually, they did not understand the material that we explained, but they were shy to ask us. We should motivate them to ask the material that they did not understand. We had to be lenient since it needed more time to explain them. Last, some students could be not controlled. They always annoyed the other students. The writer should manage the class well and need more energy to control them. Even though there were several problems during the anagram implementation actually the learning process quality was changing, which was better from the initial meeting to the last. Passive students then became active and pay more attention to each teacher's explanation in front of the class. Also, they already understood what Anagram Games was and how it was applied in their reading learning process. Finally, during the last minutes in each meeting, we conducted the test and the results of the test that they had done indicated that there was significant progress in each meeting.

The findings that had been explained indicated that Anagram Games were effective. This was supported by the average score of reading post-test that the experimental group gained was 72 and the control was 63 . In other words, the experimental group was performed better than the control group in the reading class. In addition, we also had analyzed the data using a t-test 
and we concluded that the implementation of the Anagram Games gave a positive effect on students' reading achievement than the conventional method that usually used.

\section{CONCLUSION AND SUGGESTION}

Based on the result of data analysis, it is shown that the reading achievement of the experimental group better than the control group. This research agrees that there is a positive effect of using Anagram Games on Reading Achievement of the First Grade Students in the Academic Year 2018/2019.

The implementation of Anagram is effective in the teaching and learning process since the students as the participants and the teacher as the facilitator which is suited to the curriculum 2013 that students oriented. Besides, the students have fun during the learning process the Anagram Games which employs peer-assisted make the students do not hesitate to ask their peers when they encounter some difficulties related to vocabulary. Students feel at ease when they have to ask or share their problems here, in this case, getting the meaning of unknown words or words that they considered new. The more they engage with this game the more they feel relax, calm and comfortable during reading class. This situation gives an effect on the student's comprehension. The more they add their vocabulary, the more their comprehension is increased. The Anagram Games has changed students' opinions towards reading a text, especially which has a lot of words and paragraphs. They do not regard reading as a boring and annoying activity anymore. For the teacher, this method is easier, useful and flexible to apply since there is no need for a lot of time, media, realia and place.

The purpose of the Anagram Games is to facilitate students in learning reading as a skill that has to take several steps to grasp its meaning and get the information in it. The students get more joy when they have to learn reading in a group than do it alone. Trough study in the group, students learn not only how to elaborate on their knowledge but also improve their vocabulary. Study together also can help them develop their social intelligence. This study suggests for future research implementing the Anagram Games on other skills except reading, such as speaking, listening and writing.

\section{REFERENCES}

Brown, H. D. (2004). Language assessment: Principles and classroom practices. Person Education. Inc.

Creswell, J. W., \& Creswell, J. D. (2017). Research design: Qualitative, quantitative, and mixed methods approaches. Sage publications.

Junika, D., \& Gintings, E. M. (2013). Improving students'vocabulary achievement 
through Anagram technique in SMP NI Bandar. Transform Journal of English Language Teaching and Learning of FBS UNIMED, 2(1).

Keshta, A. S., \& Al-faleet, F. K. (2013). The effectiveness of using puzzles in developing Palestinian tenth graders ' vocabulary achievement and retention. Humanities and Social Sciences, 1(1), 46-57. https://doi.org/10.11648/j.hss.20130101.16

Muslaini. (2017). STRATEGIES FOR TEACHING READING

COMPREHENSION By Muslaini * Syiah Kuala University, Banda Aceh. English Education Journal, 8(1), 66-77.

Rahman, M. A. (2016). The Effectiveness of Anagram on Students' Vocabulary Size at The Eight Grade of MTs Islamiyah Palangka Raya. State Islamic Institute of Palangka Raya.

Rraku, V. (2013). The effect of reading strategies on the improvement of the reading skills of students. Social and Natural Sciences Journal, 7(2). 